\title{
KETENCİK BİYODİZELİNİN ELDESİ İLE ÖZELLİKLERİ VE KULLANIM ALANLARI
}

Production method product properties and utilisation of camelina biodisel

Dr. M. Emin BİLGİLİ * 1

Dr. Uğur SEVİLMİş ${ }^{1}$

Dr. Seyithan SEYDOŞOĞLU ${ }^{2}$

Dr. Şerif KAHRAMAN ${ }^{3}$

Deniz SEVİLMİS ${ }^{4}$

*Sorumlu Yazar: eminbilgili@gmail.com

${ }^{1}$ Doğu Akdeniz Tarımsal Araştırma Enstitüsü, Adana

${ }^{2}$ Siirt Üniversitesi, Siirt

${ }^{3}$ GAP Uluslararası Tarımsal Araştırma ve

Eğitim Merkezi, Diyarbakır

${ }^{4}$ Yağlı Tohumlar Araştırma Enstitüsü, Osmaniye

ORCID (Yazar Sirasına Göre):
(iD) 0000-0002-4191-0540
(iD) 0000-0003-3820-8387
(D) 0000-0002-3711-3733
(iD) 0000-0003-1160-0792
(iD) $0000-0003-3030-3160$

Gönderilme Tarihi: 31 Mayıs 2019

Kabul Tarihi

\section{ÖZET}

Küresel nüfus artışına bağlı olarak sürekli artan enerji talebi, azalan fosil yakıt rezervleri ve çevresel kaygılar; gıda dışı ürünlerden yenilenebilir ve sürdürülebilir alternatif enerji kaynakları elde edilmesi zorunluluğu ortaya çıkmıştır. Yenilenebilir, toksik olmayan ve biyo-bozunur bir yakıt olan biyodizel, motor modifikasyonları olmadan dizel motorlarda kullanılabilmektedir. Fakat biyoenerji hammadde bitkileri, tarımsal alanlarda gida ve yem bitkileri ile rekabet edebilir ki bu, gıda fiyatlarının artması ve potansiyel olarak önemli ekonomik istikrarsızlaşma sonuçlarına neden olabilir. $\mathrm{Bu}$ nedenle, biyoenerji hammaddeleri üretimi için marjinal tarım alanlarının kullanılması önerilmiştir. Marjinal alanlara çok uygun olan ketencik (Camelina sativa) bitkisinin tohumları önemli bir biyoyakıt kaynağı olarak son yıllarda öne çıkmaya başlamıştır. Ketencik tohumlarının yüksek yağ içeriği (\%25-48) ve üretim maliyetinin düşük olması önemli bir avantajdır. Ketencik biyodizelinin yakıt özellikleriASTM D6751 ve EN 14214 standartlarına birçok açıdan uygun olduğu gösterilmiştir. Motor güç üretimi, $>2000 \mathrm{~d} / \mathrm{d}$ 'da mineral yakıtlara göre daha yüksek seviyededir. Ketencik 
biyodizeli mineral yakıtlara göre daha düşük $\mathrm{CO}$ ve $\mathrm{CO}_{2}$ üretmektedir. Türkiye'de EPDK motorine en az $\% 0.5$ biyodizel harmanlamasinı 2018 y1lı itibariyle zorunlu kılmıştır. Türkiye' de yıllık motorin tüketimi $29.10^{6} \mathrm{~m}^{3}$ olup bunun için $145.10^{3} \mathrm{~m}^{3}$ biyodizele ihtiyaç olduğu hesaplanmıştır.

$\mathrm{Bu}$ derlemede, konu araştırıcılarına, ketenciğin biyoyakıta dönüştürülmesi, elde edilen yakıtın özellikleri, kullanım alanları, standartları ve çevresel etkisi konusunda uluslararası alanda yapılmış çalışmaların bir özeti sunulmuştur.

Anahtar Kelimeler: Biyodizel, Camelina sativa, ketencik, Yenilenebilir enerji, Türkiye

\section{ABSTRACT}

Increasing energy demand due to global population growth, decreasing fossil fuel reserves and environmental concerns resulted with the necessity of obtaining renewable and sustainable alternative energy sources from non-food products. Biodiesel, a renewable, non-toxic and biodegradable fuel type, can be used in diesel engines without engine modifications. But bioenergy production can compete with production of food and fodder crops in agricultural areas, which can result in increased food prices and potentially significant economic destabilization. Therefore, it has been proposed to use marginal agricultural areas for the production of bioenergy raw materials. Seeds of Camelina (False flax) (Camelina sativa), which is well adopted to marginal areas, have started to be prominent crop in recent years as a suitable source for biofuels. The high oil content (25-48\%) and low production costs are important advantages of camelina. Fuel characteristics of camelina biodiesel have been shown to be suitable for ASTM D6751 and EN 14214 Standards in many respects. Motor power generation of $>2000 \mathrm{rpm}$, is higher than that of mineral fuels. Camelina produces lower $\mathrm{CO}$ and $\mathrm{CO}_{2}$ than biodiesel mineral fuels. EPDK authority of Turkey mandates to blend diesel fuel with at least $0.5 \%$ biodiesel by the year 2018. The annual diesel consumption in Turkey is close to $29.10^{6} \mathrm{~m}^{3}$ and it is estimated that $145.10^{3} \mathrm{~m}^{3}$ biodiesel is required to mix with petrodiesel.

In this review, we present a summary of internationally conducted studies on the characteristics, consumption, standards and environmental impacts of the camelina biodisel.

Keywords: Biodiesel, Camelina sativa, false flax, Renewable energy, Turkey

\section{Giriş}

Orta Asya ve Akdeniz'e özgü yağlı tohumlu bir bitki olan Ketencik [Camelina sativa (L.) Crantz], yüksek Omega-3 yağ asidi içeriği ve biyodizel yakıt olarak kullanılma olanağı nedeniyle dünya çapında popüler hale gelmiştir. Türkiye koşullarına göre yetişmesi ve diğer bitkilerle olan rekabet gücünün fazla olması ayrıca yüksek miktarda besin elementlerine 
ihtiyaç duymaması nedeniyle alternatif bir biyodizel bitkisi haline gelmiştir. Bu çalışmada, biyodizel potansiyeli ve bazı teknik özellikleri açısından ketencik bitkisi ile ilgili son gelişmeler değerlendirilmiștir.

Dünyada, artan nüfusla birlikte enerji talebinin de artması ve fosil kökenli yakıt rezervlerinin tükeniyor olması, ayrıca bu yakıtlar atmosfere karbondioksit düzeyine etki etmekle birlikte birçok çevresel sorunlara neden olmaktadır. $\mathrm{Bu}$ nedenle alternatif ve sürdürülebilir enerji araştırmalarını ortaya koymaktadır. Alternatif enerji kaynaklarının yenilenebilir, çevreci ve ülke topraklarından temin edilebilir olması, enerjisinin 3/4'ünü ithal eden Türkiye gibi ülkeler için çok önem arz etmektedir. $\mathrm{Bu}$ bağlamda bitkisel yağlar ve biyokütle bir çözüm olarak görülmektedir. Dizel motorlarda kullanılabilen alternatif yakıtların en önemlisi biyodizeldir. Çevreci ve ekonomik olması nedeniyle biyodizel üretimi önemlidir. Sainger ve ark., (2017) konvansiyonel olmayan ve yenilenebilir yakıt kaynaklarının, güneş enerjisi, rüzgar enerjisi ve biyoyakıtlar şeklinde geliştirilmesi her zamankinden daha önemli hale gelmiştir. Sürekli artan küresel enerji talebi, azalan fosil yakıt rezervleri ve çevresel kaygılar; gıda dışı ürünlerden yenilenebilir ve sürdürülebilir alternatif enerji kaynakları elde edilmesi zorunluluğu ortaya çıkmıştır.

Günümüzde dünya çapında biyodizelin \%95'inden fazlası soya ve kanola yağları gibi yenilebilir bitkisel yağlardan türetilmektedir
(Gui ve ark., 2008) ki bu gida ve yem tedarik endüstrisi ile rekabet etmektedir. Dünyada giderek artan enerji tüketimi ve yenilenebilir enerji türlerine olan talep, tarımda biyoyakıt hammadde üretiminin keskin bir șekilde yükselmesine neden olmuştur (OECD, 2019). Öte yandan, hammadde maliyeti toplam biyodizel üretim maliyetinin \%75-85'ini oluşturmaktadır ki bu nedenle, biyodizelin fiyatı genellikle petrodizelden daha yüksektir (Serra ve Zilberman, 2013). Ilıman bölgelerde ana biyoyakıt hammadde ürünleri mısır, kolza ve soyadır (UNEP, 2009). Dünyanın en büyük ikinci biyodizel üreticisi olan $\mathrm{ABD}$ (Çanakci ve Şanl1, 2008), ürettiği biyodizelinin yaklaşık \%85'ini soya yağından üretmektedir. Biyodizel endüstrisinin artan talebinin karşıllanması ve diğer yakıtlara karşı ekonomik olarak rekabetçi olması için yeni nesil, geleneksel olmayan ve düşük maliyetli hammaddeler gerekmektedir (Soriano ve Narani, 2012). Ketencik yağ içeriğinin, birkaç araştırma grubu tarafindan\%25-48 arasında değiştiği bildirilmiştir (Zubr, 1997; Zubr, 2003).

Ketencik, yaygın olarak yetiştirilen yağlı tohum bitkisi Brassica napus ile benzer üretim uygulamalarına sahiptir (Séguin-Swartz ve ark., 2009). Kısa vejetasyon süresi ile biyotik ve abiyotik streslere olan tolerans1, ketenciğin Brassica napus'a kıyasla, hem daha "kuzey enlemlerde" hem de daha "kurak alanlarda" yetiştirilebilmesine olanak tanımaktadır (Singh ve ark., 2015). Lošák ve ark., (2011), ketenciğin, ağır, su basma sorunu olan, asit topraklar ve yabancı otlu araziler hariç hemen hemen her türlü 
toprakta yetiştirilebileceğini bildirmişlerdir.

Ketencik, tarım alanlarından marjinal alanlarının değerlendirebileceği alternatif bir yağ bitkisidir. Düşük çevre isteği ve ürünlerinin yaygın olarak kullanılabilirliği sayesinde bitki büyük ilgi görmüştür. Besin ve besin endüstrisi dışında olmak üzere çok geniş kullanım potansiyeline sahip olması nedeniyle ketencik geleceğin önemli alternatif yağ bitkileri arasında, yakın bir gelecekte yerini alacaktır.

\section{Ketencikten biyodizel eldesi}

Ketencik önemli bir biyoyakıt kaynağı olarak ileri çıkmaktadır (Ghamkhar ve ark., 2010). Ketencik tohumlarının yüksek yağ içeriği (\%2548) Zubr, 2003 ve (>\%90 doymamış yağ asitleri), bitkinin kısa yaşam döngüsü, düşük tarımsal girdi gereksinimi, çeşitli biyotik ve abiyotik streslere göreceli toleransı ile birleştiğinde önemi ortaya çıkmaktadır (Ayaşan, 2014).

Ketencikhasatveharmanlamadansonrakurutulur. Ketencikte mekanik presleme, farklı şekillerde gerçekleştirilebilen, tohumların işlenmesinde ana yöntemdir. Diğer bir yöntem ise, ketencik tohumlarını mekanik baskıda kavrulmuş macun olarak preslemedir. $\mathrm{Bu}$ yöntemde, tohumlar, karışıma hamurlu bir görünüm verecek şekilde eşit miktarda su ile karıştırılır. Daha sonra macun $60-90{ }^{\circ} \mathrm{C}$ de kavrulur ve işlemin sonras1, karışım kumsu hale gelir. Kavrulmuş macun mekanik bir presle sıkılır ve yağı çıkarılır. Son olarak, yağ berraklaştırmak için süzülür (Rode, 2002). Bir başka benzer yöntem ise ketencik tohumları temizledikten sonra, tohumlarından yağ, su eklenmeden bir expeller-press ile de çıkarılabilmektedir. Expeller-press içinde üretilen basınç ve 1S1, yağı tohumlardan kolayca çıkarmaktadır. Bu işlemlerin sonunda, ketencik yağ1 ve yağl1 tohum keki üretilmektedir.

Ketencik yağ 1 yaklaşı $\% 15$ gondik asit (20:1 n9) ve yaklaşık \%3 erusik asit (22:1 n9) içermektedir. Bu iki yağ asidi, Cruciferae familyasına ait bitki tohumlarından elde edilen yağlarda tipik olarak bulunmaktadır (Abramovic ve ark., 2005). Çalışmalar, ketencikteki linolenik asit içeriğinin kanola, soya ve zeytinyağından yaklaşık 2-4 kat daha yüksek olduğunu ortaya koymaktadır (Crowley ve Fröhlich, 1998; Karvonen ve ark., 2002).

Ketencik tohumlarının yağı yüksek oranda linolenik ( $\sim 32)$, linoleik $(\sim \% 19)$ ve oleik ( $\% 18)$ yağ asitleri nedeniyle, ketencik yağından türetilen metil ve etil esterler, kanola, palm ve soya yağları ile karşılaştırıldığında, oksidatif stabilitesi idealden daha düşük ve iyot değerleri yüksek düzeydedir (Abramovic ve Abram, 2005; Moser ve Vaughn, 2010). Bununla birlikte, diğer yakıt özellikleri bu diğer biyodizellere benzemektedir. Örneğin, ketencik elde edilen yağın metil esterlerinin viskozitesinin $40^{\circ} \mathrm{C}$ de 2.9 ila $3.15 \mathrm{~mm}^{2} \mathrm{~s}^{-1}$ olduğu, bunun normal dizel viskozitesiyle karşılaştırılabilir $\left(2.6 \mathrm{~mm}^{2} \mathrm{~s}^{-1}\right)$ olduğu bildirilmiştir (Acharjee, 2011). 
Doymamış yă̆ asitlerinin yüksek içeriği nedeniyle, ketencik tohumu yağı hızlı kuruyan yağlar grubuna dahildir ki bu nedenle çevre dostu polimerler, cilalar ve boyalar üretmek için kullanılmaktadır. Ayrıca, bu yağ türü bazı ilaçların yapımına uygundur (Zaleckas ve ark., 2012). Ketencik yağ1, \%90 doymamış yă̆ asidi içeriği nedeniyle biyopolimer endüstrisi için umut verici bir malzemedir. Epoksitlenmiş ketencik yağı, basınca duyarlı yapıştırıcılar, kaplamalar ve reçineler alanında potansiyel endüstriyel uygulamalara sahiptir (Kim ve ark., 2015). Ketencik, biyodizel ester üretimi için pozitif enerji dengesine sahiptir (net enerji oranı 1.47) (Sahapatsombut ve Suppapitnarm, 2006).

Bitkisel yağlar, transesterifikasyon adı verilen bir işlem yoluyla bir katalizör varlığında, alkoliz yoluyla biyodizel üretmek için kullanılabilen doğal olarak oluşan trigliseritlerdir. Biyodizel üretiminde en yaygın kullanılan alkol metanoldür. $\mathrm{Bu}$ kimyasal reaksiyonun ana yan ürünü gliserol'dür. Ana yağın transesterifikasyonu, teorik olarak ana yağın yağ asidi profiline sahip olan yağ asidi metil esterleri (FAME) üretmektedir (Soriano ve Narani, 2012). Transesterifikasyon işleminden elde edilen biyodizel verimini ifade etmenin iki yolu vardır: ürün verimi ve yağ asidi metil esterleri verimi. Ürün verimi, ham yağdanüretilebilecek biyodizel miktarını gösterir. Yağ asidi metil esterleri verimi ise, biyodizelin kalitesinin bir göstergesi olan, biyodizeldeki yă̆ asidi metil esterleri miktarıdır. Transesterifikasyon işleminde ortaya çıkan biyodizelin miktarı ve kalitesi, reaksiyon sicaklığı, reaksiyon süresi, metanol/yağ mol oranı ve katalizör konsantrasyonu gibi bazı reaksiyon değişkenlerinden de etkilenmektedir. $\mathrm{Bu}$ işlem parametrelerinin, verim ve kaliteyi en üst düzeye çıkarmak için optimize edilmesi gerekmektedir. Transesterifikasyon sirasinda bir katalizörün uygulanması reaksiyon verimliliğinde önemli bir rol oynamaktadır. Birçok araştırmacı transesterifikasyonu arttırmak için asit, baz ve enzim gibi farklı katalizörler kullanmıştır. Baz katalizörlerin, düşük maliyet, düşük reaksiyon sıcaklıkları ve kısa reaksiyon süreleri nedeniyle, asit ve enzim katalizörlerine kıyasla endüstriyel ölçekte biyodizel üretimine en uygun katalizörler olduğu kabul edilmiştir (Atadashi ve ark., 2013). Baz katalizör olarak, biyodizel üretimi için, en tipik olarak potasyum hidroksit $(\mathrm{KOH})$ ve sodyum hidroksit $(\mathrm{NaOH})$ kullanılmaktadır. Yüksek miktarda metanol ilavesi, transesterifikasyon işlemini artırarak, yüksek bir FAME veriminin elde edilmesini sağlamaktadır (Rashid ve ark., 2008). Reaksiyon sıcaklığı ve süresi de biyodizel üretimi için kritiktir, ancak farklı hammaddeler ve uygulanan yağ miktarı ile değişmektedir.

Çoklu doymamış yağ asidi içeriğinin yüksek olmasından dolayı, ketencik yağından elde edilen metil esterlerin, kolza yağından elde edilen metil esterlerle karışım halinde biyodizel yakıt olarak kullanılabileceğini göstermiştir (Mittelbach ve Remschmidt, 2004).

Ketencik, biyodizel üretimi ile ilgili birkaç çalışma yapılmış olmasına rağmen, transesterifikasyon reaksiyon koşullarının 
optimizasyonu tam olarak araştırılmamıştır (Yang, 2016). Transesterifikasyondan üretilen ham ketencik biyodizelinde, alkol, katalizör, su, gliserol, reaksiyona girmemiş mono-, di- ve trigliseritler, serbest yağ asitleri ve sabun gibi bir dizi saflığı bozucu madde bulunmaktadır (Atadashi ve ark., 2011; Stojković ve ark., 2014).
(Lingfeng ve ark., 2007). Alkali metal oksitler, biyodizel sentezi için temel heterojen katalizörler olarak geniş ölçüde çalışılmıştır (Mootabadi ve ark., 2010). Kalsiyum oksit, normal koşullar altında elde edilebilirliği, düşük maliyeti ve mükemmel katalitik performansı nedeniyle özellikle iyi bir transesterifikasyon katalizörüdür (Kawashima et al., 2009).

Heterojen katalizörlerin kullanılması, sabun oluşumuna neden olmamakta ve nötralizasyona gereksinimi ortadan kaldırmaktadır. Heterojen katalizörlerle reaksiyonlar daha basit biyodizel ayırma ve saflaştırma adımlarına sahiptir. Heterojen katalizörler atık su üretmezler ve sıv1 ürünlerden süzülerek kolayca ayrılabilirler ve daha yüksek aktivite, seçicilik ve daha uzun ömür sağlayacak şekilde tasarlanabilirler (Tanabe ve Hölderich, 1999). Çevresel etkiyi ve işlem maliyetini azaltan bu katalizörler yeniden kullanılabilir. Homojen katalizörler yerine heterojen katalizörlerin kullanılması potansiyel olarak daha ucuz üretim maliyetlerine ve sabit yataklı bir sürekli işlemde iş görebilmektedir

\section{Ketencik biyodizelinin özellikleri}

Şimşek ve Aydoğan, (2016), yapılan deneysel çalışmalar sonucunda ketencik biyodizelinin yapısındaki oksijen bütün koşullarda yanma verimine katkı sağlayarak $\mathrm{CO}, \mathrm{HC}$ ve pusluluk değerleri azalmış, $\mathrm{CO}_{2}$ ile $\mathrm{NO}_{\mathrm{x}}$ değerleri artmıştır. Aynı çalışma sonucunda ketencik biyodizelinin common rail yakit enjeksiyon sistemli bir motorda herhangi bir değişiklik yapılmadan kullanılabileceği ifade edilmiştir.

Ketencik yağı ile dizel yakıtının bazı özelliklerinin karşılaştırılması Çizelge 1'de Çizelge 2'de verilmiştir. verilmiştir. Ketencik biyodizelinin özellikleri ise

Çizelge 1. Ham ketencik yağı ve dizel yakıt özelliklerinin karşılaştırılması (Özçelik ve ark., (2015)).

\begin{tabular}{|l|l|l|}
\hline Özellikler & Ketencik yağı & Dizel yakıtı \\
\hline Yoğunluk $15^{\circ} \mathrm{C}\left(\mathrm{kg} / \mathrm{m}^{3}\right)$ & 918 & 838 \\
\hline Kinematik viskozite $40^{\circ} \mathrm{C}\left(\mathrm{mm}^{2} / \mathrm{s}\right)$ & 24 & 2.92 \\
\hline Parlama noktası $\left({ }^{\circ} \mathrm{C}\right)$ & $>220$ & 102 \\
\hline Alt 1 s1l değeri $(\mathrm{MJ} / \mathrm{kg})$ & 38 & 42.3 \\
\hline Kül $(\% \mathrm{kütle})$ & 0.0025 & 0.01 \\
\hline Kükürt $(\mathrm{mg} / \mathrm{kg})$ & 13.85 & 9 \\
\hline Su içeriği $(\mathrm{mg} / \mathrm{kg})$ & 710 & 43.8 \\
\hline Asit değeri $(\mathrm{mg} \mathrm{KOH} / \mathrm{g})$ & 1.39 & - \\
\hline İyot sayısı $(\mathrm{g} . \mathrm{I} / 100 \mathrm{~g})$ & 151.5 & - \\
\hline
\end{tabular}


4. Ketencik biyodizelinin motorlarda ve jetlerde kullanımı

Rudolf Diesel'in 1893 y1lında icat ettiği dizel motorda yakıt olarak Afrika kökenli yer fıstığı yağını kullanmasına rağmen, günümüze kadar enerji içeriği daha yüksek olan fosil kökenli yakıtlar, dizel motorlarda daha yaygın olarak kullanılmıştır. Oksijenli yakıtların egzoz emisyonlarını azaltmadaki başarısı ve artan çevre bilinci biyodizel olarak adlandırılan yă̆ asitlerinin dizel motorlarında kullanımını 1980’li yılların başında tekrar gündeme getirmiştir. Bitkisel yağlar bazı kritik zamanlarda (19301940 ve 1973 petrol krizi gibi) sadece acil durumlar için dizel motorlarda kullanılmıştır. Fakat bitkisel yağların dizel yakıtına kıyasla viskozitelerinin ve moleküler ağırlığının daha yüksek olması, zayıf yakıt atomizasyonuna; içeriğinde gliserin bulundurması, silindir içerisinde tortulara, yapışkan maddelere, karbon birikimine neden olmaktadır. Bu durum, bitkisel yağ kullanılan motorlarda ciddi problemler oluşturmuştur. Bitkisel, hayvansal veya atık bitkisel yağların dizel motorunda herhangi bir değişiklik yapılmadan kullanılabilmesi için dizel yakıtına yakın özelliklere sahip bir yakıta dönüştürülmesi gerekmektedir (Şimşek ve Aydoğan 2016).

Ketencik bitkisel yağının doğrudan biyoyakıt olarak kullanımına ilişkin ilk sonuçlar Bernardo ve ark. (2003) tarafından tanımlanmıştır. Modifiye edilmemiş dizel motorlarda tek başına yakıt olarak uygulanabilirliğini mineral dizel yakıtla karşılaştırmak amacıyla doğrudan soğuk preslenmiş ve filtrelenmiş ketencik yağı kullanmıştır. Ketencik yağı, mineral yakıta kıyasla maksimum güç çıktısını artırmış (38.50 kW'a kıyasla $43.25 \mathrm{~kW}$ ) ve daha fazla yakıt tüketimine sebep olmuştur $(14.03 \mathrm{~km} / \mathrm{l}$ ile karşılaştırıldığında 12.57 km/1).

Ketencik yağından üretilen biyodizel (transesterifikasyon sonrası yağ asidi esterleri), soya yağından üretilen biyodizelinkilere benzer yakıt özelliklerine (düşük sıcaklıkta çalışabilirlik, asit değeri, kinematik viskozite, kayganlık, setan sayısı vb.) sahiptir (Moser ve Vaughn, 2010).

American Society for Testing and Materials (ASTM) teknik özelliklerini onayladığından, ketencik biyokaroseni, havayolu şirketleri için tercih edilen yenilenebilir yakıt olarak ayrıcalıklı bir konuma sahiptir. Ketencikten elde edilen biokerosene ABD Ordusu, Japonya Havayolları, Iberia ve Embraer tarafindan başarıyla test edilmiştir. Farklı uçak ve motorlarda farklı hızlarda çeşitli denemeler yapılmıştır (Falasca ve ark., 2014). Ketencik yağından elde edilen biyodizel, Japonya havayolları (JAL) ve KLH Royal Dutch havayolları tarafından başarıyla test edilmiştir (Shonnard ve ark., 2010).

Triasilgliserollerden jet yakıtı veya biyodizel yapmak için, gliserolün çıkarılmasından sonra, doymamış yağ asit kısımlarının hidrojenlenmesi ve ardindan orta zincirli C10-C14 ve k1sa zincirli C6-C9 hidrokarbonlara dönüştürülmesi gerekmektedir (Bouchy ve ark., 2009). Bu işlemler maliyetlidir ve enerji tüketmektedir $(\mathrm{Hu}$ ve ark., 2017).

Yeni biyodizel yakıt türlerini üretirken, yalnızca 
fiziksel ve kimyasal özelliklerini değil, aynı zamanda konvansiyonel biyodizel yakitının özelliklerine kıyasla, motorda karşılaştırmalı performans testleri yapmak gereklidir. Ketencik yağından türetilen biyodizel yakıtın motor performansı nispeten düşük olduğu belirtilmiştir (Lebedevas ve ark., 2010).

\section{Ketencik biyodizelinin standartları}

Tohumlar, ketencik bitkisinin ekonomik olarak en önemli kısmıdır (Kagale ve ark., 2014). Ketencik yağı temel olarak, 1sı veya kimyasal madde uygulanmadan, mekanik prosedürlerle, soğuk presleme yoluyla elde edilir ki bu, Codex Alimentarius'a uygundur (CODEX, 2005). Bu tür yağlar kimyasal olarak rafine edilmezler ve sadece su ile yıkayarak, santrifüjleme, filtreleme veya çökeltme yoluyla saflaştırılabilmektedir (Hrastar ve ark., 2012; CODEX, 2005). Yağ, ketencik tohumlarından çözücü ekstraksiyonla veya mekanik presleme yoluyla (Giampietro ve ark., 1997) veya bu işlemlerin kombinasyonuyla ekstrakte edilebilmektedir.

Ketencik yağının metil esteri için setan sayis1, ASTM biyodizel standartlarından daha yüksek olan 49.26-51.17 olarak bulunmuştur ki daha yüksek setan sayıs1, iyi bir yakıt tutuşma kalitesini göstermektedir. Ketencik yağının metil esterlerinin akma noktasının $-11^{\circ} \mathrm{C}$ ile $-8^{\circ} \mathrm{C}$ arasında olduğu tahmin edilmektedir ki, bu da soğuk mevsim koşullarına yakıtın iyi bir şekilde uyduğunu göstermektedir. Ketencik esteri ile taşıt kullanımı ve yakıt tüketimi, kolza tohumunun metil esteri ile benzerdir (Frohlich ve Rice,
2005). ASTM D 6751 biyodizel standartlarına göre serbest gliserin sinırı \%0.02 ve toplam gliserin (serbest + bağlı) sınırı \%0.24'tür ve ketencik biyodizeli içindeki serbest ve toplam gliserin içeriği sırasıyla ağırlıça \%0.018 ve \%0.195'dir. Düşük seviyedeki serbest ve toplam gliserin, ketencik yağının metil estere dönüşümünün yüksek olmasını sağlamaktadır (Patil ve Deng, 2009). Ketenciğin yağ içeriğinin, birkaç araştırma grubu tarafindan \%25-48 arasında değiştiği bildirilmiştir (Zubr, 1997; Zubr, 2003).

Ketencik biyodizelinin yakıt özelliklerinin çoğu (kinematik viskozite, asit sayısı, parlama noktası, kükürt içeriği, toplam gliserol gibi), ASTM D6751 ve European standard (EN 14214) spesifikasyonları ile uyumludur. Setan sayısı (49.7) ASTM D6751'e göre ümut vardır ancak EN 14214 için uygun değildir. Ketencik biyodizeli, yüksek oranda çoklu doymamış yağ asidi metil esterleri nedeniyle düşük oksidatif stabilite (1.9 saat) göstermiştir (Yang, 2016).

Ketenciğin B5 karışımları (\%95 dizel ile \%5 alkil monoester), $2.38 \mathrm{~mm}^{2} \mathrm{~s}^{-1}$ kinematik viskozitelerini göstermiştir ki bu standartlar 1.9$4.1 \mathrm{~mm}^{2} \mathrm{~s}^{-1}$ aralığını kapsamaktadır (Moser ve Vaughn, 2010). Bu değer, petrodizel standard1 ASTM D975'e ve petrodizel-biyodizel karışımı standard1 ASTM D7467'e göre tatmin edicidir (ASTM, 2008, Campbell ve ark., 2013). Ayrica bu standartlarda düşük emisyonlar da istenir ki Bernardo ve ark., (2003)'nın yürüttüğü çalışmada, ketencik, mineral yakıtlardan daha düşük $\mathrm{CO}, \mathrm{CO}_{2}$ ve duman üretmiş ve $>2000 \mathrm{rpm}$ motor devrinde mineral yakıtlardan daha fazla 
güç üretmiştir.

Ciubota-Rosie ve ark., (2013), ketencik biyodizelinin zayıf oksidatif stabilite (1.3 saat) ve düşük setan sayısı (42.8) gösterdiğini ve her ikisinin de ASTM D6751'e uymadığını; bununla birlikte, ketencik biyodizelinin diğer özelliklerinden düşük sıcaklıkta çalışabilirlik (bulutlanma noktası ve soğuk dalma filtrasyon testi), viskozite, damıtma özellikleri ve az miktarda karbon kalıntısı ve kükürt içeriği ile ASTM D6751 ile iyi bir uyum sağladığını bildirmişlerdir. Bununla birlikte, Moser ve Vaughn, (2010), ketencik biyodizelinin setan sayısının (52.8) ASTM D6751 minimum spesifikasyonunu (47) karşıladığını, ancak oksidatif stabilitesinin yeterli olmadığını bildirmiştir.

Wu ve Leung, (2011), maksimum ketencik biyodizel ürün verimi (\%95.8) ve FAME verimine (\%98.4), \%1 katalizör (potasyum hidroksit, $\mathrm{KOH}$ ) konsantrasyonu, 70 dakika reaksiyon süresi ve $50^{\circ} \mathrm{C}$ reaksiyon sıcaklığı ile ulaşıldığını göstermiştir.

Gliserol yan üründür ve çoğunluğu yoğunluk ve polarite farkından dolayı faz ayrılması yoluyla biyodizelden çıkarılabilir, ancak eser miktarda gliserol biyodizelde kalabilir. ASTM D6751 biyodizeldeki toplam gliserolün ağırlıkça \%0.24'ten düşük olması gerektiğini belirtmektedir. Bu sınırın aşılması, yakıt hatlarını ve pompaları tıkayabilecek istenmeyen birikintilere neden olacaktır. Bitkisel yağda doğal olarak bulunan serbest yağ asitleri, $\mathrm{KOH}$ veya $\mathrm{NaOH}$ gibi katalizörlerle reaksiyona girebilir ve sabun oluşturabilir ki buna transesterifikasyona paralel olarak gerçekleşen sabunlaşma denir. Gliserole benzer şekilde, yüksek sabun içeriği motorun aşınma problemlerine neden olabilmekte ve motorun ömrünü olumsuz yönde etkileyebilmektedir (Atadashi ve ark., 2011; Stojković ve ark., 2014). ASTM D6751'de belirgin bir sabun içeriği spesifikasyonu olmamasına rağmen, KOH'nin biyodizel üretim sürecinde katalizör olarak kullanılması durumunda genel olarak kabul edilebilir sabun sınırı 66 ppm'den düşüktür. Dizel motor silindirinde potasyum veya sodyumla zenginleştirilmiş biyodizel yakarken kül üretilebilir. Biyodizeldeki serbest yă asidi yüzdesi asit sayısıyla yakından ilişkilidir (50.5 mg KOH/g) ve yüksek serbest yăg asidi seviyesi dizel motor bileşenlerinin korozyonuna neden olabilir. Biyodizelde aşırı su içeriğinin ( $\leq 500$ ppm; ASTM D6751'de) bulunmas1 yak1t yanmasının 1sı verimliliğini azaltabilmekte, yă asidi metil esterlerinin hidrolizini artırabilmekte ve hatta düşük sıcaklık koşullarında yakıtların jelleşmesine neden olan buz kristalleri oluşturabilmektedir (Atadashi, 2015; Stojković ve ark., 2014). Bu nedenle, biyodizel spesifikasyonlarını tam olarak karşılamak için ham biyodizeldeki gliserol, metanol ve sabun içeriğini azaltmak veya en aza indirmek için uygun saflaştırma işlemleri gereklidir. Genel olarak, ham biyodizeli saflaştırmanın iki yolu vardır: sulu yıkama ve kuru yıkama. Suyla yıkama, ham biyodizelde suda çözünür safsızlıkları gidermek için kullanılan geleneksel yoldur. Her ne kadar suyla yıkama, ham biyodizelin verimli bir şekilde saflaştırılmasını 
mümkün kılsa da, bu ıslak yıkama saflaştırma işlemi çevre üzerinde zararlı bir etkiye sahip olan çok büyük miktarda atık su ve sulu atık madde üretmektedir. İyon değiştirme reçinesi, biyodizel saflaştırması için yoğun olarak araştırılan bir kuru yıkama ortamı türüdür (Yang, 2016). Filtrasyon, ham biyodizelden çözünmeyen safsızlıkları filtreleyebilen ve adsorpsiyon, polar gözenekler ve adsorban parçacıklarının yüzeyi nedeniyle kimyasal etki yoluyla çözünür safsızlıkları giderebilen fiziksel bir işlemdir. İyon değişimi, sabundaki sodyum veya potasyum iyonları gibi safsızlıkların kimyasal parçalanması ve bunların reçineden gelen hidrojen iyonu ile değiştirilerek serbest yağ asitleri oluşturulması işlemidir.

Ham yă̆ asidi bileşiminin doymamışlık derecesi, biyodizel oksidatif stabilitesi için en önemli faktördür (Yang, 2016). Depolama süresi boyunca biyodizelin oksidatif stabilitesini etkileyebilecek diğer faktörler arasında ortam havası, 1şık, yüksek sıcaklık, az miktarda katalitik metal, saklama kabı malzemesi ve peroksitler bulunmaktadir (Knothe, 2007). Havayla temas, depolama süresi boyunca biyodizelin otoksidasyonuna neden olan başlica faktördür ki, hava ile biyodizel arasındaki temas alanının azaltılması biyodizel otoksidasyonunu en aza indirebilmektedir (Knothe, 2006). Otoksidasyon, oksidatif stabilite indeksi (OSI) veya Indüksiyon periyodu (IP) ile karakterize edilmektedir. Biyodizelin oksidatif stabilite indeksi veya indüksiyon süresi EN 14112' deki standart test yöntemi olan Rancimat yöntemiyle ölçülebilmektedir. Otoksidasyon, numunelerin içinden geçen havanın sekonder oksidasyon ürünlerinin (uçucu organik asitler) ortaya çıkmasına yol açması için geçen süredir. Dolayısıyla, daha yüksek bir oksidatif stabilite indeksi daha iyi bir oksidatif stabiliteyi temsil etmektedir. Antioksidanların yağ veya biyoyakıtlara eklenmesi oksidasyon başlangıcını geciktirebilmekte ve antioksidan tükenene kadar indüksiyon periyodunu arttırabilmektedir (Bondioli ve ark., 1995; Dunn, 2008). Tipik olarak, bitkisel yağlardan üretilen biyodizelin, biyodizel standartları EN14214 (8 saat) veya ASTM D6751 (3 saat)'deki oksidatif stabilite ihtiyacını karşılamak için uygun miktarda antioksidan ile işlenmesi gerekmektedir. Bitkisel yağlarda doğal olarak oluşan E vitamini (tokoferoller ve tocotrienoller) gibi antioksidanlar, doğal antioksidanlar olarak adlandırılmaktadır. Biyodizeldeki doğal antioksidanlar, transesterifikasyon işleminden önce bitkisel yağın rafine edilme işleminden etkilenebilmektedir (Fernández ve ark., 2010). Bütillenmiş hidroksitolüen (BHT), bütillenmiş hidroksianizol (BHA), tertbütilhidrookinon (TBHQ) ve propil gallat (PrG) gibi farklı sentetik antioksidanlar da vardır. $\mathrm{Bu}$ sentetik antioksidanlar biyodizel oksidatif stabilitesini arttırmak için biyodizel içine eklenebilir. Bununla birlikte, bu antioksidanların etkinliği farklıdır. Diğer yandan, antioksidanların yükleme konsantrasyonu da etkinliklerinde önemli bir rol oynamaktadir (Yang, 2016). Dunn, (2005) PrG, BHT ve BHA'nın soya esteri için en etkili antioksidanlar olduğunu ve $\alpha$-Tokoferol'ün en az etkili olduğunu bildirmiştir. Bu çalışma, 3000 ppm'ye kadar BHAyükleme konsantrasyonunun, uzun süreli depolama sırasında oksidasyonu 
etkili bir şekilde azaltabileceğini göstermiştir.

Kuzey Amerika'da ASTM D6751 ve Avrupa Birliği'nde EN 14214 de dahil olmak üzere titiz bir yakıt spesifikasyonu seti, saf biyodizelin (B100) saf bir yakıt olarak kullanılmadan veya petrodizelle karıştırılmadan önce uyması gereken parametreleri tanımlamak için geliştirilmiştir. Parlama noktas1, biyodizelin hava ile yanıc1 bir karışım oluşturacağı en düşük sıcaklıktır. Parlama noktası, depolama ve nakliye sirasında biyodizelingenelyanıcılıkriskinideğerlendirmek için önemli bir parametredir. Metanol içeriği parlama noktası için kritiktir, çünkü metanol biyodizelden daha yanıcıdır. Biyodizelde yüksek metanol içeriği düşük parlama noktasına neden olur. Bulut noktası, biyodizelin gözlemlenebilir hidrokarbon kristalleri kümelerine sahip olmaya başladığg veya bulutlu olmaya başladığı en düşük sıcaklığı belirtir. Bulutlanma noktası düşük sıcaklıklarda biyodizel akışkanlığının temsili bir parametresidir. Setan sayısı, bir referans yakıtla (saf C16: 0) karşılaştırarak motorun içindeki biyodizel ateşleme performansının bir ölçüsüdür. Setan sayısı, biyodizelin yanması sırasında biyodizelin ne kadar hızlı yanmaya başladığını gösterir. Asit sayısı, biyodizelin asitlik seviyesini belirten bir parametredir ve yüksek asit sayısı lastik elemenlara ve diğer motor elemanlarına zarar verebileceği için önemlidir (Yang, 2016).

Ketenciğin biyodizel (Moser ve Vaughn, 2010) ve biokerosen üretimi için uygun olduğu kanıtlanmıştır (Shonnard ve ark., 2010). Ketencik tohumu yağı, biyodizel yakıt üretiminde kullanılabilir; bununla birlikte, yüksek çoklu doymamış asit içeriği nedeniyle, biyodizel yakıtı, iyot değeri açısından EN 14214: 2003 Standardına uymaması muhtemeldir. $\mathrm{Bu}$ problem, doymuş yağ asidi içeriğine sahip yağların karıştırılmasıyla çözülebilir. Ketencik yağından biyodizel yakıt üretiminde katk1 için olası yağ, hayvansal yăg olabilmektedir (Zaleckas ve ark., 2012).

Ciubota-Rosie ve ark., (2013) tarafindan ketencik biyodizelini bir biyo-yakıt alternatifi olarak değerlendirmek için, Avrupa ve Amerika standartlarına (EN 14214 ve ASTM D6751) göre kapsamlı bir karakterizasyon yapılmıştır. İlk defa, otuzdan fazla parametre analiz edilmiştir. Sonuçlar, ketencik yağının yaklaşık olarak \%90 oranında doymamış yağ asidi içerdiğini göstermiştir. Bu olağandışı yağ asidi yapısı, C18: 1 (\%12.8-14.7), C18:2 (\%16.3-17.2), C18:3 (\%36.2-39.4) ve C20:1 (\%14.0-15.5) yağ asitleri içeriğinin bolluğunun sonucu olmuştur. Yüksek C18:3 içeriği EN 14214 spesifikasyonları ile uyumlu değildir ve setan sayısı, iyot değeri, oksidasyon kararlılığı ve linolenik asit metil ester içeriği gibi biyodizel özelliklerini olumsuz yönde etkilemektedir. Diğer kritik parametreler atmosferik eşdeğer sicaklık (AET, \%90'1 geri kazanılmış) ve çoklu doymamış ( $\geq 4$ çift bağ) metil ester içeriğidir. $\mathrm{Bu}$ nedenlerden ötürü ketencik, biyodizel uygulamaları için ciddi dezavantajlar sunsa da, eğer yüksek derecede doymamışlık derecesi ve yağın moleküler ağırlı̆̆ 1 azaltılırsa, iyi bir biyodizel hammaddesi olabileceği tespit edilmiştir.

Şimşek ve Aydoğdu, (2016) yaptıkları çalışmada ketencik biyodizeli ve karışımlarının common rail yakit enjeksiyon sistemine sahip bir dizel 
Çizelge 2. Ketencik biyodizelinin yakıt özellikleri (Özçelik ve ark., 2015)

\begin{tabular}{|l|l|l|l|}
\hline Yakıt Özellikleri & EN 14214: 2012 & Ketencik biyodizel & Test metodu \\
\hline Yoğunluk $\left(15^{\circ} \mathrm{C} \mathrm{kg} / \mathrm{m}^{3}\right)$ & $860-900$ & $885-888$ & EN ISO 12185 \\
\hline Kinematik viskozite $\left(40^{\circ} \mathrm{C} \mathrm{mm} / \mathrm{s}\right)$ & $3.5-5$ & $4.53-5.45$ & EN ISO 3104 \\
\hline Soğukta filtre tıkanma noktası $(\mathrm{CFPP}){ }^{\circ} \mathrm{C}$ & - & -3 & EN 116 \\
\hline Bulutlanma noktas1 ${ }^{\circ} \mathrm{C}$ & - & 3 & EN 23015 \\
\hline Metil ester içeriği $(\mathrm{wt} \%)$ & 96.5 & 97.5 & EN 14103 \\
\hline Alevlenme noktası $\left({ }^{\circ} \mathrm{C}\right)$ & 101 & 202 & EN ISO 3679 \\
\hline Kükürt içeriği $(\mathrm{mg} / \mathrm{kg})$ & 10 & 0.59 & EN ISO 20846 \\
\hline Karbon kalıntıs1 $(\mathrm{wt} . \%)$ & 0.30 & 0.019 & EN ISO 10370 \\
\hline Su içeriği $(\mathrm{mg} / \mathrm{kg})$ & 500 & 120 & EN ISO 12937 \\
\hline Bakır korozyon testi $\left(3 \mathrm{~h}, 50^{\circ} \mathrm{C}\right)$ & 1 & $1 \mathrm{~A}$ & EN ISO 2160 \\
\hline Oksidasyon kararlılı̆ $1\left(110^{\circ} \mathrm{C}\right) \mathrm{h}$ & 8 & $1.3-2.2$ & EN 14112 \\
\hline Asit değeri $(\mathrm{mgKOH} / \mathrm{g})$ & 0.50 & 0.36 & EN 14214 \\
\hline İyot sayısı max. $(\mathrm{g} . \mathrm{I} 2 / \mathrm{g})$ & 120 & 154 & EN 14111 \\
\hline
\end{tabular}

motorunda yakıt olarak kullanımında emisyon değerleri karşılaştırılmıştır. Yapılan deneysel çalışmalar sonucunda Ketencik biyodizelinin yapısındaki oksijen bütün koşullarda yanma verimine katkı sağlayarak $\mathrm{CO}, \mathrm{HC}$ ve pusluluk değerlerini azaltmış, $\mathrm{CO}_{2}$ ile NOx değerleri artmıştır. Bahsedilen bu çalışma sonucunda ketencik biyodizelinin "common rail yakıt enjeksiyon sistemli" bir motorda herhangi bir değişiklik yapılmadan kullanılabileceği görülmüştür.

\section{Ketencik biyodizelinin çevresel etkisi}

Yenilenebilir, toksik olmayan ve biyo-bozunur bir yakıt olan biyodizel, motor modifikasyonları olmadan dizel motorlarda kullanılabilmektedir. Biyodizel konvansiyonel dizel yakıttan daha temiz yanmakta; karbon monoksit, hidrokarbonlar, partikül madde oluşumunu önemli ölçüde azaltmakta ve kükürt dioksit emisyonlarını elimine etmektedir (Ma ve Hanna, 1999). Atmosfere net karbondioksit katk1s1 yoktur ve dizel ile karşılaştırıldığında sera gazı emisyonlarını \%41 azaltmaktadır (Manuel, 2007). Ek olarak, biyodizel yüksek oranda setan sayısına, yüksek parlama noktasına ve her oranda petrol dizeli ile mükemmel karışabilirliğe sahiptir (Knothe, 2008).

Bernardo ve ark., (2003)'nın yürüttüğü çalışmada, ketencik, mineral yakıtlardan daha düşük $\mathrm{CO}, \mathrm{CO}_{2}$ ve duman üretmiştir. Duman opasitesi ve karbon monoksit üretimi, ketencik yağında, mineral dizel yakıttan \%50 daha az olmuştur.

Havacılıkta kullanılan ketencik kaynaklı biokerosen, petrol kerosenine kiyasla sera gazı emisyonlarında \%84 azalma göstermiştir (Falasca ve ark., 2014). 
SONUÇ

Marjinal alanlara çok uygun olan ketencik bitkisinin tohumları önemli bir biyoyakıt kaynağı durumundadır. Dünyada bu konuda yeni ve artan oranda araştırma ve geliştirme çalışmaları yürütülmektedir. Ayrıca halihazırda bu ürüne yatırım yapan firmalar batılı ülkelerde mevcuttur ve sayıları artış göstermektedir.

Birçok özellik açısından ketencik yağı biyodizel olarak kullanıma uygundur. Biyodizel olarak kullanımını zorlaştıran faktörler, ketencik yağının diğer yağlarla karıştırılması yoluyla ortadan kaldırılabilmektedir. Ayrica yeni olan sslah yoluyla iyileştirilmesi faaliyetleri, ileride hızla daha üstün çeşitlerin ortaya çıkmasına ve tohumlarının yağının daha fazla iyileștirilmesine yardımcı olacak gibi görünmektedir. Ülkemizde de, marjinal alanlar için çok uygun olan bu türün geliştirilmesi ve biyodizel amaçlı kullanımı konusunda ileri çalışmaların yapılması gerekmektedir.

Ketencik tohumlarının yüksek yağ içeriği (\%25-48) ve üretim maliyetinin düşük olması önemli bir avantaj sağlamaktadır. Ketencik biyodizelinin yakıt özellikleri ASTM D6751 ve EN 14214 Standartlarına göre uygun olduğu setan sayısının ASTM D6751'e göre 42.8-52.8 arasında gösterilmiştir. Motor güç üretimi $>2000 \mathrm{~d} / \mathrm{d}$ 'da mineral yakıtlara göre daha fazla elde edilebilmektedir. Ketencik mineral yakıtlara göre daha düşük $\mathrm{CO}$ ve $\mathrm{CO}_{2}$ üretmektedir. Türkiye'de, EPDK motorine en az \%0.5 biyodizel harmanlamasını 2018 yılı itibariyle zorunlu kılmıştır. Bu bağlamda, ortalama y1llık motorin tüketimi $29.10^{6} \mathrm{~m}^{3}$ olup bunun için $145.10^{3} \mathrm{~m}^{3}$ biyodizele ihtiyaç olduğu hesaplanmıştır.

Sonuç olarak; ketencik bitkisinin düşük üretim girdi maliyeti, yüksek yă̆ oranı elde edilmesi ve marjinal tarım alanlarında yetiştirilebilmesi büyük bir önem taşımaktadır. Türkiye'de biyodizel açığının bu tür bir bitki ile karşılanması makro düzeyde ekonomik fayda sağlayacaktır. 


\section{KAYNAKÇA}

Abramovic, H., \& Abram, V. 2005. Physicochemical properties, composition and oxidative stability of Camelina sativa oil. Food Technol. Biotechnol, 43(1), 63-70.

Acharjee, T. C. 2011. Exploring the Potential Use of Camelina sativa as a Biofuel crop for Nevada. University of Nevada, Reno.

ASTM, 2008. Standard specification for diesel fuel oil, biodiesel blend (B6 to B20), Method D7467-08a. In 'Annual Book of ASTM Standards'. (ASTM International: West Conshohocken, PA).

Atadashi, I. M. 2015. Purification of crude biodiesel using dry washing and membrane technologies.Alexandria Engineering Journal, 54(4), 1265-1272.

Atadashi, I. M., Aroua, M. K., \& Aziz, A. A. 2011. Biodiesel separation and purification: a review. Renewable Energy, 36(2), 437443.

Atadashi, I. M., Aroua, M. K., Aziz, A. A., \& Sulaiman, N. M. N. 2013. The effects of catalysts in biodiesel production: A review. Journal of industrial and engineering chemistry, 19(1), 14-26.

Ayaşan, T. 2014. Ketencik Bitkisinin (Camelia sativa) Kanatlı Beslenmesinde Kullanılması. Kahramanmaraş Sütçü İmam Üniversitesi Doğa Bilimleri Dergisi, 17(2), 10-13.

Bernardo, A., Howard-Hildige, R., O’Connell,
A., Nichol, R., Ryan, J., Rice, B., \& Leahy, J. J. 2003. Camelina oil as a fuel for diesel transport engines. Industrial Crops and Products, 17(3), 191-197.

Bondioli, P., Gasparoli, A., Lanzani, A., Fedeli, E., Veronese, S., \& Sala, M. 1995. Storage stability of biodiesel. Journal of the American Oil Chemists' Society, 72(6), 699-702.

Bouchy, C., Hastoy, G., Guillon, E., \& Martens, J. A. 2009. Fischer-Tropsch waxes upgrading via hydrocracking and selective hydroisomerization. Oil \& Gas Science and Technology-Revue de l'IFP, 64(1), 91-112.

Campbell, M. C., Rossi, A. F., \& Erskine, W. 2013. Camelina (Camelina sativa (L.) Crantz): agronomic potential in Mediterranean environments and diversity for biofuel and food uses. Crop and Pasture Science, 64(4), 388-398.

Çanakci, M., \& Şanlı, H. 2008. Biodiesel production from various feedstocks and their effects on the fuel properties. Journal of industrial microbiology \& biotechnology, 35(5), 431-441.

Ciubota-Rosie, C., Ruiz, J. R., Ramos, M. J., \& Pérez, Á. 2013. Biodiesel from Camelina sativa: a comprehensive characterisation. Fuel, 105, 572-577.

CODEX, S. 2005. STAN 210-1999. Codex standard for named vegetable oil. Codex Alimentarius. Amendment, 2011, 2013. 
Crowley, J. G., \& Fröhlich, A. 1998. Factors affecting the composition and use of camelina. Teagasc.

Dunn, R. O. 2005. Oxidative stability of soybean oil fatty acid methyl esters by oil stability index (OSI). Journal of the American Oil Chemists' Society, 82(5), 381-387.

Dunn, R. O. 2008. Antioxidants for improving storage stability of biodiesel. Biofuels, Bioproducts and Biorefining: Innovation for a sustainable economy, 2(4), 304-318.

Falasca, S. L., del Fresno, M. C., \& Waldman, C. 2014. Developing an agro-climatic zoning model to determine potential growing areas for Camelina sativa in Argentina. QScience Connect, 4.

Fernández, C. M., Ramos, M. J., Pérez, Á., \& Rodríguez, J. F. 2010. Production of biodiesel from winery waste: extraction, refining and transesterification of grape seed oil. Bioresource technology, 101(18), 7019-7024.

Frohlich, A., \& Rice, B. 2005. Evaluation of Camelina sativa oil as a feedstock for biodiesel production. Industrial crops and products, 21(1), 25-31.

Ghamkhar, K., Croser, J., Aryamanesh, N., Campbell, M., Kon'kova, N., \& Francis, C. 2010. Camelina sativa (L.) Crantz as an alternative oilseed: molecular and ecogeographic analyses. Genome, 53(7), 558-567.
Giampietro, M., Ulgiati, S., \& Pimentel, D. 1997. Feasibility of large-scale biofuel production. BioScience, 47(9), 587-600.

Gui, M. M., Lee, K. T., \& Bhatia, S. 2008. Feasibility of edible oil vs. non-edible oil vs. waste edible oil as biodiesel feedstock. Energy, 33(11), 1646-1653.

Hrastar, R., Abramovič, H., \& Košir, I. J. 2012. In situ quality evaluation of Camelina sativa landrace. European Journal of Lipid Science and Technology, 114(3), 343-351.

Hu, Z., Wu, Q., Dalal, J., Vasani, N., Lopez, H. O., Sederoff, H. W., \& Qu, R. (2017). Accumulation of medium-chain, saturated fatty acyl moieties in seed oils of transgenic Camelina sativa. PloS one, 12(2), e0172296.

Kagale, S., Koh, C., Nixon, J., Bollina, V., Clarke, W. E., Tuteja, R., \& Higgins, E. E. 2014. The emerging biofuel crop Camelina retains a highly undifferentiated hexaploid genome structure. Nature communications, 5, 3706 .

Karvonen, H. M., Aro, A., Tapola, N. S., Salminen, I., Uusitupa, M. I., \& Sarkkinen, E. S. 2002. Effect of [alpha]-linolenic acid [ndash] rich Camelina sativa oil on serum fatty acid composition and serum lipids in hypercholesterolemic subjects. Metabolism-Clinical and Experimental, 51(10), 1253-1260.

Kawashima, A., Matsubara, K., \& Honda, K. 
2009. Acceleration of catalytic activity of calcium oxide for biodiesel production. Bioresource Technology, 100(2), 696-700.

Kim, N., Li, Y., \& Sun, X. S. 2015. Epoxidation of Camelina sativa oil and peel adhesion properties. Industrial Crops and Products, 64, 1-8.

Knothe, G. 2006. Analysis of oxidized biodiesel by $1 \mathrm{H}-\mathrm{NMR}$ and effect of contact area with air. European journal of lipid science and technology,108(6), 493-500.

Knothe, G. 2007. Some aspects of biodiesel oxidative stability. Fuel Processing Technology, 88(7), 669-677.

Knothe, G. 2008. "Designer” biodiesel: optimizing fatty ester composition to improve fuel properties. Energy \& Fuels, 22(2), 1358-1364.

Lebedevas, S., Lebedeva, G., Makarevičiene, V., Kazanceva, I., \& Kazancev, K. 2010. Analysis of the ecological parameters of the diesel engine powered with biodiesel fuel containing methyl esters from Camelina sativa oil. Transport, 25(1), 2228.

Lingfeng, C., Guomin, X., Bo, X., \& Guangyuan, T. 2007. Transesterification of cottonseed oil to biodiesel by using heterogeneous solid basic catalysts. Energy \& Fuels, 21(6), 3740-3743.

Lošák, T., Hlusek, J., Martinec, J., Vollmann, J., Peterka, J., Filipcik, R., \& Martensson,
A. (2011). Effect of combined nitrogen and sulphur fertilization on yield and qualitative parameters of Camelina sativa [L.] Crtz.(false flax). Acta Agriculturae Scandinavica, Section B-Soil \& Plant Science, 61(4), 313-321.

Ma, F., \& Hanna, M. A. 1999. Biodiesel production: a review. Bioresource technology, 70(1), 1-15.

Manuel, J. 2007. Battle of the biofuels. Environmental health perspectives, 115(2), A92.

Mittelbach, M., \& Remschmidt, C. 2004. Biodiesel. The compherensive handbook (No. L-0577).

Mootabadi, H., Salamatinia, B., Bhatia, S., \& Abdullah, A. Z. 2010. Ultrasonic-assisted biodiesel production process from palm oil using alkaline earth metal oxides as the heterogeneous catalysts. Fuel, 89(8), 1818-1825.

Moser, B. R., \& Vaughn, S. F. 2010. Evaluation of alkyl esters from Camelina sativa oil as biodiesel and as blend components in ultra low-sulfur diesel fuel. Bioresource Technology, 101(2), 646-653.

OECD, 2019. OECD Stats - OECD-FAO agricultural outlook 2018-2027 MetaData: biofuel. OECD-FAO Agricultural Outlook 2011-2020, https://stats.oecd.org/index. aspx?queryid=30104 (Erişim 22.01.2019).

Özçelik, A.E., Aydoğan, H., Acaroğlu, M., 2015. 
Determining the performance, emission and combustion properties of camelina biodiesel blends, Elsevier, Selçuk Üniversitesi, Energy Conversion and Management 96.47-57.

Patil, P. D., \& Deng, S. 2009. Transesterification of camelina sativa oil using heterogeneous metal oxide catalysts. Energy \& Fuels, 23(9), 4619-4624.

Rashid, U., Anwar, F., Moser, B. R., \& Ashraf, S. 2008. Production of sunflower oil methyl esters by optimized alkali-catalyzed methanolysis. Biomass and bioenergy, 32(12), 1202-1205.

Rode, J. 2002. Study of autochthon Camelina sativa (L.) Crantz in Slovenia. Journal of herbs, spices \& medicinal plants, 9(4), 313-318.

Sahapatsombut, U., \& Suppapitnarm, A. 2006. Assessment of new potential cropsJatropha curcas and Camelina sativa for sustainable energy resources in Thailand. In International Conference on Green and Sustainable Innovation, Thailand.

Sainger, M., Jaiwal, A., Sainger, P. A., Chaudhary, D., Jaiwal, R., \& Jaiwal, P. K. 2017. Advances in genetic improvement of Camelina sativa for biofuel and industrial bio-products. Renewable and Sustainable Energy Reviews, 68, 623-637.

Séguin-Swartz, G., Eynck, C., Gugel, R. K., Strelkov, S. E., Olivier, C. Y., Li, J. L., \& Falk, K. C. 2009. Diseases of Camelina sativa (false flax). Canadian Journal of Plant Pathology, 31(4), 375-386.

Serra, T., \& Zilberman, D. 2013. Biofuel-related price transmission literature: A review. Energy Economics, 37, 141-151.

Shonnard, D. R., Williams, L., \& Kalnes, T. N. 2010. Camelina-derived jet fuel and diesel: Sustainable advanced biofuels. Environmental Progress \& Sustainable Energy, 29(3), 382-392.

Singh, R., Bollina, V., Higgins, E. E., Clarke, W. E., Eynck, C., Sidebottom, C., \& Parkin, I. A. 2015. Single-nucleotide polymorphism identification and genotyping in Camelina sativa. Molecular breeding, 35(1), 35.

Soriano Jr, N. U., \& Narani, A. 2012. Evaluation of biodiesel derived from Camelina sativa oil.Journal of the American Oil Chemists' Society, 89(5), 917-923.

Stojković, I. J., Stamenković, O. S., Povrenović, D. S., \& Veljković, V. B. 2014. Purification technologies for crude biodiesel obtained by alkali-catalyzed transesterification. Renewable and Sustainable Energy Reviews, 32, 1-15.

Şimşek, R., ve Aydoğan, H. 2016. "Ketencik Biyodizelinin Üretimi ve Common Rail Enjeksiyon Sistemli Bir Motorun Emisyonlarına Etkisi”. Uluslararası Yakıtlar, Yanma ve Yangın Dergisi, Say1 (4), 60-64.

Tanabe, K., \& Hölderich, W. F. 1999. Industrial application of solid acid-base catalysts. Applied Catalysis A: General, 181(2), 
399-434.

UNEP, 2009. Towards Sustainable Production and Use of Resources: Assessing Biofuels. United Nations Environment Programme, Nairobi.

Wu, X., \& Leung, D. Y. 2011. Optimization of biodiesel production from camelina oil using orthogonal experiment. Applied Energy, 88(11), 3615-3624.

Yang, J. 2016. Evaluating The Feasibility of Biodiesel Production from Camelina Sativa.

Zaleckas, E., Makarevičienė, V., \& Sendžikienė, E. 2012. Possibilities of using Camelina sativa oil for producing biodiesel fuel. Transport, 27(1), 60-66.

Zubr, J. 1997. Oil-seed crop: Camelina sativa. Industrial crops and products, 6(2), 113119.

Zubr, J. 2003. Qualitative variation of Camelina sativa seed from different locations. Industrial Crops and Products, 17(3), 161169. 